\title{
3. BASEMENT LITHOSTRATIGRAPHY, DEEP SEA DRILLING PROJECT HOLE 504B ${ }^{1}$
}

\author{
Andrew C. Adamson, Department of Geology, The University, Newcastle upon Tyne ${ }^{2}$
}

\begin{abstract}
The lithostratigraphy of the $1075.5 \mathrm{~m}$ of basement drilled in Hole 504B on the Costa Rica Rift is described. A method of classifying basalts into lithologic types (massive types A and B, dikes, sheet flows, thin flows, pillow basalts) is proposed, and is used to construct a standardized lithologic column, modifying the lithology previously described by the shipboard scientific parties for Legs 69,70 , and 83 .

The oceanic basement at Hole 504B can be divided into three lithologic zones: an upper zone (the upper $571.5 \mathrm{~m}$ of basement) consisting of a complex association of intercalated pillow lavas, pillow breccias, hyaloclastic, massive units (flows and sills), synflows, and localized flow and tectonic breccias; a transition zone ( $209 \mathrm{~m}$ thick), consisting of pillow lavas, synflows, massive units, and dikes; and a lower zone (the deepest $295 \mathrm{~m}$ cored and probably extending deeper) consisting predominantly of massive units and dikes. The lithostratigraphy of Hole 504B is essentially concordant with that of ophiolite complexes, and supports the ophiolite model for ocean crust structure.
\end{abstract}

\section{INTRODUCTION}

Hole 504B is located on the southern flank of the Costa Rica Rift in the eastern equatorial Pacific. The hole was drilled in three separate stages during DSDP Legs 69,70 , and 83 . It reaches a total depth of $1350 \mathrm{~m}$ below seafloor (BSF), or $1075.5 \mathrm{~m}$ into basement, and it is currently the deepest penetration into in situ oceanic crust in the world. The hole forms a unique reference section through the upper oceanic crust.

For the first time it has been possible to study the nature of the upper oceanic crust, in situ and to compare it with existing models of its structure, the probable nature of which has been controversial since the mid 1970s. Two models have been proposed. The first, based on the structure of ophiolite complexes, considers the structure of the ocean floor to be the same as, or very similar to, that of the ideal ophiolite. This is a layered structure, composed of pelagic sediments underlain by effusive (pillow) basalts, which grade downward into a sheeted dike complex. This in turn grades into a sequence of gabbros and finally ultramafic cumulates (Gass, 1968; Moores and Vine, 1971; Cann, 1970, 1974). The second model is based on a mélange structure and was formulated to account for the findings of DSDP Leg 37, which drilled half a kilometer into the ocean basement in the North Atlantic. It proposes that the upper part of the ocean crust (at least the top $500 \mathrm{~m}$ ) consists of a series of faulted blocks which have rotated and subsided during transportation away from the ridge, producing a mélange (Hall, 1979). Hole 504B gives an opportunity to contrast these two structural models and to see which most closely resembles the actual crustal structure in the Costa Rica Rift.

This chapter describes the lithostratigraphy of Hole 504B, as compiled from rock recovery and geophysical

\footnotetext{
${ }^{1}$ Anderson, R. N., Honnorez, J., Becker, K., et al., Init. Repts. DSDP, 83: Washington (U.S. Govt. Printing Office).

2 Present address: Ocean Drilling Program, Texas A\&M University, College Station, TX 77843-3469.
}

logging, and presents the first full-length lithological column for Hole 504B. The two structural models are briefly contrasted at the end of the chapter. The column has been constructed using the following sources of information: the visual core descriptions and thin section descriptions for Legs 68-70 (1981) and Leg 83 (1982); the lithostratigraphic accounts of Hole 504B in CRRUST (1982) for Legs 69 and 70, and in Anderson et al. (1982a) for Leg 83; the lithostratigraphic diagram for the top $836 \mathrm{~m}$ of the hole (Legs 69 and 70) in Volume 69 of the Initial Reports, and in CRRUST (1982); and the diagram of the lower $514 \mathrm{~m}$ for Leg 83 in Anderson et al. (1982b) and in this volume.

\section{LITHOLOGICAL TYPE DEFINITIONS}

In constructing Figure 1, I have made no alterations to the position or total number of existing lithological units as identified by the shipboard petrologists from core recovery. I have found it necessary sometimes to subdivide these units into several sections, particularly in the Legs 69 and 70 portions of the hole, but have decided not to renumber these units. I have looked at the rocks forming each lithological unit and, using the parameters of changing grain size, occurrence of glassy margins, and fractured appearance, have allocated the unit to one of six different lithological types, as defined below.

1. Massive. These are divided into two types: (a) basalts which are medium to very coarsely grained and little affected by drilling; core is recovered in long intact pieces (these units are dominant in the upper portion of the hole); (b) basalts which are medium to coarse grained but affected by drilling; the cores break into generally short pieces (these units are dominant in the lower portion of the hole).

2. Dikes. A dike is a unit with one or two chilled intrusive margins.

3. Sheet flows. These are characterized by parallel, closely spaced (under $0.5 \mathrm{~m}$ apart), mainly horizontal, flat glassy selvages, distinct from the rounded or inclined margins of pillow units. 

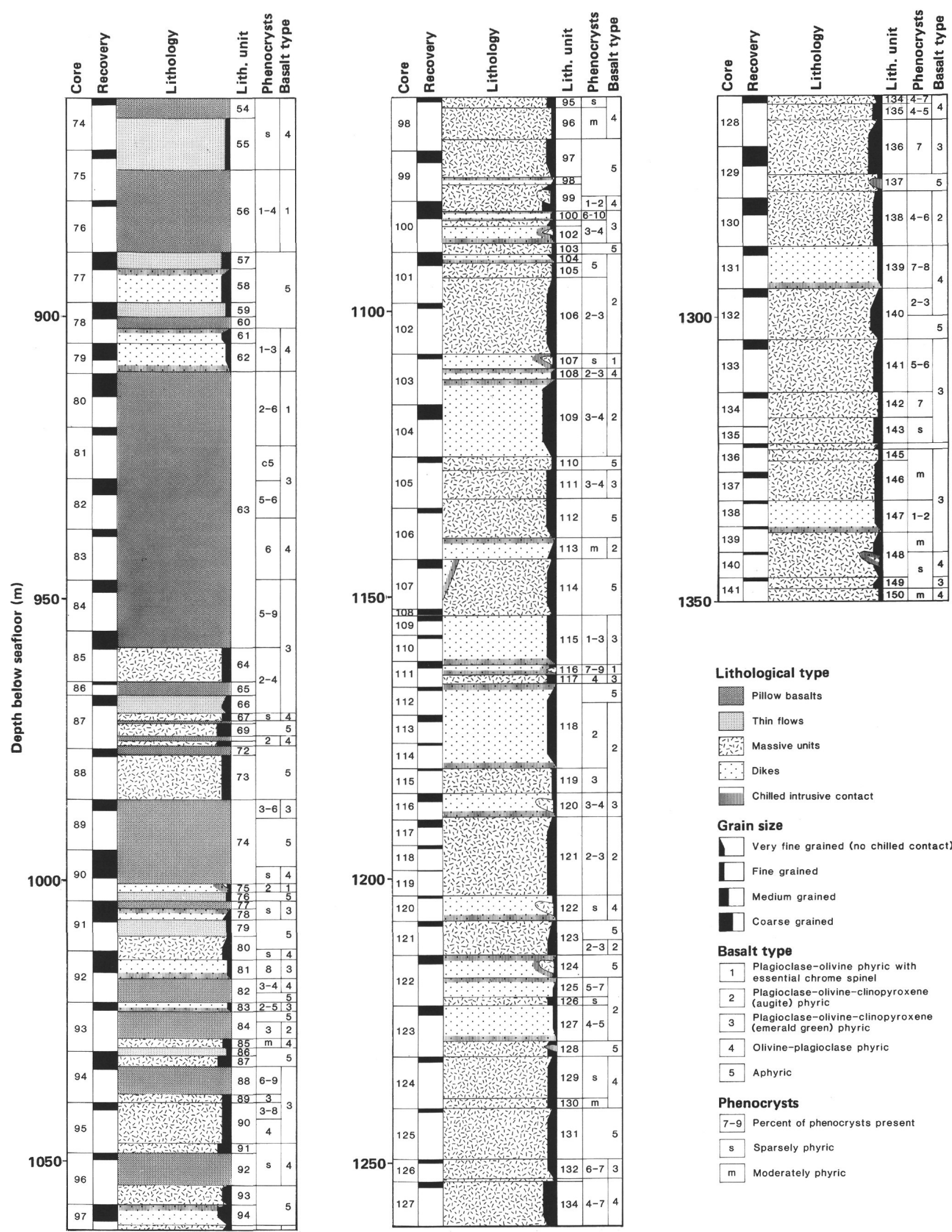

\section{Lithological type}

Pillow basalts

$\square$ Thin flows

Massive units

$\therefore$ Dikes

Chilled intrusive contact

\section{Grain size}

$\square$ very fine grained (no chilled contact)

$\square$ Fine grained

प Medium grained

Coarse grained

\section{Basalt type}

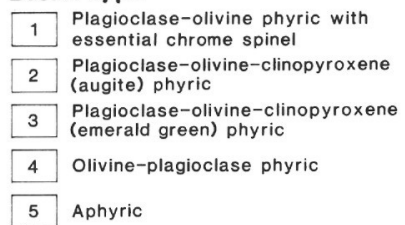

\section{Phenocrysts}

7-9 Percent of phenocrysts present

$\mathrm{s}$ Sparsely phyric

m Moderately phyric

Figure 1. Basement lithostratigraphy of Hole 504B. The transition zone begins with Unit 51 ( $846 \mathrm{~m}$ BSF). The lower zone begins with Unit 93 (1055 m BSF). The two types of massive units (Types $1 \mathrm{a}$ and $1 \mathrm{~b}$ - see text) are not distinguished on this figure. Phenocryst content determined by hand specimen and/or thin section study. In all cases, $\mathrm{c}$ before the number indicates that phenocryst content is approximate. Basalt type classification is that of Natland et al. (1983), but with the addition of an aphyric group. Additional information upon the phenocrysts is as 

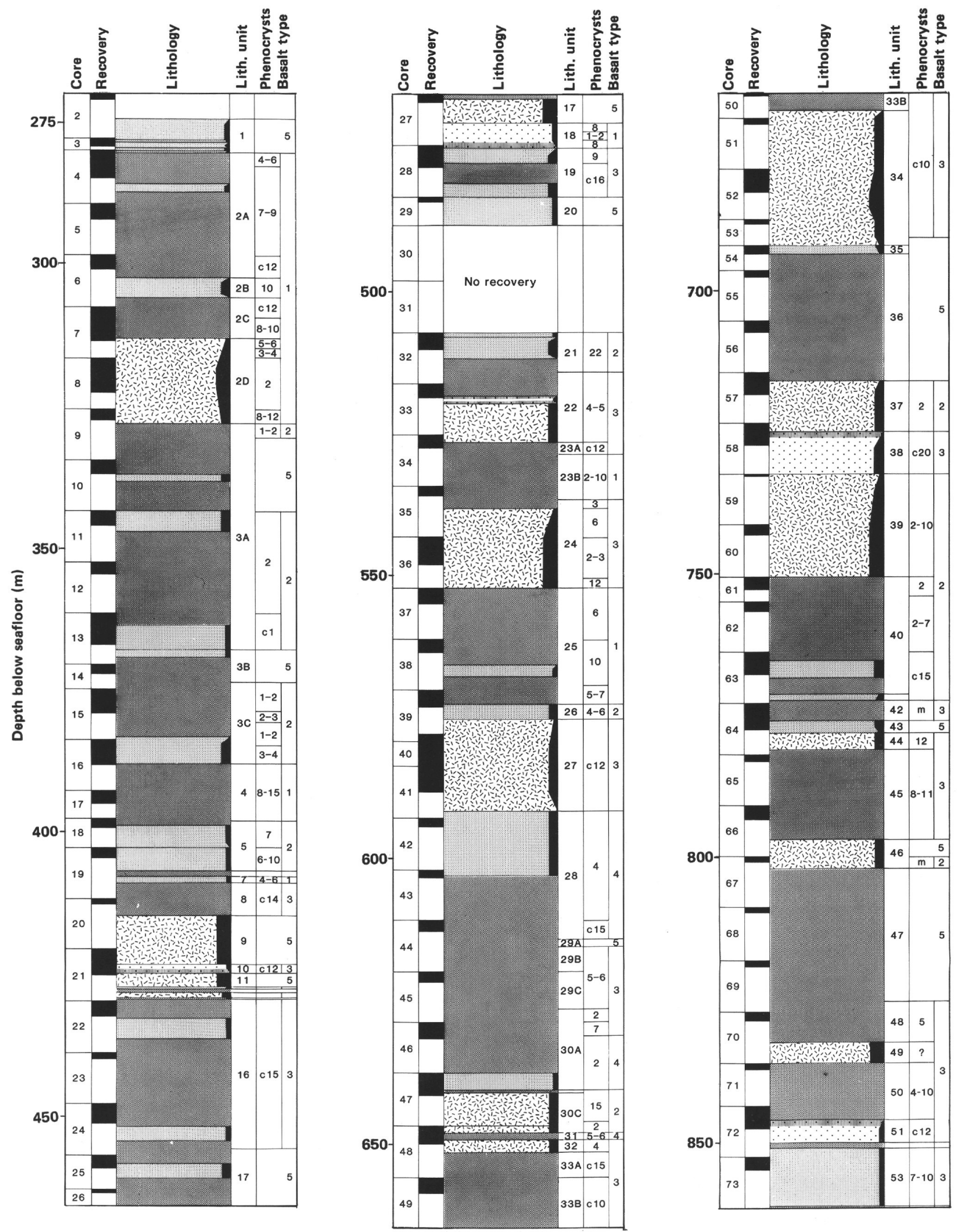

Figure 1. (Continued).

follows: Unit 6 has $10 \%$ phenocrysts of petrographic type 3 (Unit $6 / 10 \% / 3$ ), Unit $12 / \mathrm{c} 12 \% / 3$, Unit $13 / 0 \% / 5$, Unit $14 / \mathrm{cl} 12 \% / 3$, Unit $15 / 0 \% / 5$, Unit 30B/10\%/2, Unit 41/c15\%/2, Unit 52/8-9\%/4, Unit 68/0\%/5, Unit $70 / 2 \% / 4$, Unit $101 / \mathrm{s} / 3$, Unit $133 / \mathrm{s} / 4$, and Unit $141 / 0 \% / 5$. 
4. Thin flows. These are recognized by homogeneous areas of core in excess of $1 \mathrm{~m}$ thick (i.e., thicker than the average pillow), formed by fine- to medium-grained basalts.

5. Pillow basalts. All material remaining after the preceding lithological types are identified is considered to consist of pillow basalts. They are characterized by the presence of chilled pillow margins (mostly curved or inclined), hyaloclastic breccias, and fine-grained, often highly fractured rocks.

Using this classification scheme, a consistent interpretation and allocation of material to one of the lithological types is possible, irrespective of recovery. Figure 1 can, therefore, be considered as standardized throughout. In constructing this figure, the depth of each lithologic boundary has been calculated following a procedure different from the standard DSDP procedure of assigning all material recovered in a core to the top of the cored interval, with voids then assigned to the bottom of the interval. Instead, in this study the thickness of recovered material in each core was scaled to encompass the entire cored interval. Thus the thicknesses of the lithologic units as identified by the shipboard petrographers were also scaled by a factor equal to the length of the cored interval divided by the length of recovered material within the cored interval.

\section{LITHOSTRATIGRAPHY OF HOLE 504B}

Reference to Figure 1 clearly shows that the basement at Hole 504B is composed of at least two separate zones with a boundary at the bottom of Unit 92 . The petrologists from Leg 83, however, felt there was sufficient evidence to support a three-tier division of the crust into an upper zone, transition zone, and lower zone. These are described as follows.

\section{The Upper Zone (274.5-846 m BSF)}

The upper zone lies in the top $571.5 \mathrm{~m}$ of basement (i.e., 274.5-846 m BSF) and consists of a complex association of intercalated pillow lavas, pillow breccia, hyaloclastites, massive units (flows or sills), thin flows, and localized flow and tectonic breccias.

A number of cores recovered from this zone contain long lengths of full-diameter core clearly recognizable as massive cooling units (lithologic Type $1 \mathrm{a}$, earlierUnits 2D, 24, 27, and 34). Their thicknesses can be calculated from Figure 1. Lithological thickness may be up to $25 \mathrm{~m}$, although a thickness of 15 to $17 \mathrm{~m}$ is more common. A more realistic value for thickness can be attained by determining the total recovery from each unit (loss of material due to drilling is probably minimal in such competent horizons) or, alternatively, by reference to the downhole logs (see Cann and Von Herzen, 1983; Newmark et al., this volume). Thicknesses are then in the order of $6-12+\mathrm{m}$ (for example, Unit $2 \mathrm{D}$ is $9.8 \mathrm{~m}$ thick, 24 is $6.0 \mathrm{~m}, 27$ is $11.8 \mathrm{~m}$, and 34 is $6.3 \mathrm{~m}$ ). These compare favorably with the thicknesses quoted for massive flows by Kidd (1977) in Cyprus (10-40 m thick), and by Bodvarsson and Walker (1964) in the Tertiary basalt flows of Iceland (10 $\mathrm{m}$ average thickness). These units are sufficiently thick to be quite coarse grained and nearly holocrystalline in their interiors (CRRUST, 1982). They can be recognized on the logs as zones of high but uniform density, resistivity, and sonic velocity. There are two likely origins for these massive units. First, they may represent thick flows erupted when the hole was still relatively close to the spreading axis; or alternatively, sill-like bodies injected through the pillows by intruding dikes. A confident allocation to either type is not possible because no margins were retrieved.

These thick, massive zones form only a small proportion of the rocks drilled. Several coarse-grained but relatively thin horizons are evident. Lithologically they are in the order of 2 to $5 \mathrm{~m}$ thick (e.g., sections within Units $3 \mathrm{~A}, 17,26$, and 40 ); only about $0.5-2 \mathrm{~m}$ per unit were, however, recovered $(3 \mathrm{~A}, 0.3 \mathrm{~m}$ thick, $17,0.5 \mathrm{~m}, 26$, $1.7 \mathrm{~m}$, and $40,1.2 \mathrm{~m}$ ). These would be considered as rather coarse-grained, thin flows, using the unit definitions discussed earlier. In most cases the relatively low recovery precludes them from being classified as massive flows (Type 1b, earlier), although their coarseness suggests that they may be more closely related to massive units than to true thin flows. It would seem unlikely that a basalt flow $2 \mathrm{~m}$ thick could develop a medium- to coarse-grained texture. Possibly these units are sills or the less fractured portions from tectonized massive flows. Additional evidence for this can be found in the downhole logging diagrams of Cann and Von Herzen (1983), where many such units are associated with zones of low porosity characteristic of the massive units discussed earlier.

Thin sheet flows as defined earlier can be found in two main sections of the hole, located in Units 1 and 21. These can vary from 0.5 to $4 \mathrm{~m}$ thick (depicted lithologically), but in terms of recovery are very much thinner. The five flows in Unit 1, for example, have a total recovery of only about $2 \mathrm{~m}$, giving an average thickness of less than $0.5 \mathrm{~m}$. The well-defined, flat, glass margins associated with these thin units suggest a probable origin as some form of sheet flow. Similar glass margins are described by Natland and Rosendahl (1980) from the East Pacific Rise (Leg 54); in their case thicknesses are in the order of 0.1 to $0.15 \mathrm{~m}$. Flows such as these will have undoubtedly have been underestimated in Hole 504B; Units 1 and 21 contain only the most obvious examples. An attempt was made to isolate flat selvages as indicators of sheet flows, because most flat selvages are horizontal. Evidence from the dike unit, however, suggests the crust was tilted up to about $30^{\circ}$ after formation (see later discussion). This would be consistent with the model formulated by Cann (1974) for the postformational processes acting on the ocean crust. Thus choosing horizontal flat margins as indicators of sheeted flows may not be altogether correct. Work by Kidd (1977) on the Cyprus ophiolite shows the dip of the lavas in the upper part of the crust is in the main subhorizontal; only the lower part of the lavas dips up to $30^{\circ}$ toward the spreading axis. Possibly semi-inclined flat selvages would have been a better choice for identifying sheeted flows.

The vast majority of thin flows recognized in the upper part of Hole 504B are of the fine-grained variety, Type 4 above; recovery was usually about $1-2 \mathrm{~m}$. Several 
have associated glass margins (units in $2 \mathrm{~A}, 3 \mathrm{C}, 5,19$, and 25). Thin flows seem to be most common in the Leg 69 portion of the hole, intercalated with pillows, in contrast to the Leg 70 section of the upper zone where massive units and pillows dominate the lithology. It is of interest to calculate the relative proportions of pillow lavas to thin flows and massive units: in the upper $200 \mathrm{~m}$ of the hole (calculated in lithological terms, not by actual recovery), pillows form about $54 \%$ of the total. This compares favorably with the findings of Lonsdale and Spiess (1980), who looked at the proportions of lava types in the axial plateau of the East Pacific Rise by deep-tow survey, and found that pillows made up $60 \%$ of the outcrop, and with those of Hall and Robinson (1979), who found pillows to form $55 \%$ of drilled material in the North Atlantic.

All the pillowed units encountered during drilling are highly fractured, with fracture frequency per meter of recovered material several times that of massive cooling units (see Natland and Adamson, unpublished data). Glass margins in pillowed units were recovered throughout the upper zone of the hole often associated with hyaloclastites. Pillow thicknesses vary irregularly down the hole from as little as 0.3 up to about $0.8 \mathrm{~m}$ thick (e.g., Section 504B-4-1, pillow thickness $=0.35 \mathrm{~m}$; 504B-4-2 $=0.8 \mathrm{~m} ; 504 \mathrm{~B}-5-1=0.7 \mathrm{~m} ; 504 \mathrm{~B}-6-1=0.3 \mathrm{~m}, 0.35 \mathrm{~m}$, $0.35 \mathrm{~m} ; 504 \mathrm{~B}-7-1=0.4 \mathrm{~m}, 0.45 \mathrm{~m} ; 504 \mathrm{~B}-10-1=0.7 \mathrm{~m}$; 5-4B-13-1 $=0.4 \mathrm{~m}$; and 504B-25-2 $=0.55 \mathrm{~m}$ ). No estimate is possible in the highly fractured Cores 19-21 and 27-29 (Natland and Adamson, unpublished data) where no pillows appear to have remained intact. Borehole televiewer pictures of pillows from Hole 504B indicate thicknesses in the order of $0.2-0.3 \mathrm{~m}$ (see also Newmark et al., this volume). Pillow diameters measured from the core are close to pillow diameters of $0.5 \mathrm{~m}$ quoted by Kidd (1977) for Cyprus.

\section{The Transition Zone (846-1055 m BSF)}

The upper zone is underlain by a transition zone consisting of $209 \mathrm{~m}$ of pillows, thin flows, massive units, and dikes. The upper boundary of the transition zone is at $846 \mathrm{~m}$ BSF, where four dikes occur within $60 \mathrm{~m}$ of each other (Units 51, 58, 61, and 62). The shipboard petrologists believed that this rapid increase in dike abundance signified a change in basement character and the beginning of a transition zone. Dikes were identified by the intrusive nature of the contacts seen in hand specimen and thin section. As described by Anderson et al. (1982a), contacts can vary from brecciated to razor sharp. In contrast to pillow rims, dike margins contain no glass and extensive quench morphologies are rare (see also Kempton et al., this vol.).

Pillow sequences are more abundant, continuous, and heavily brecciated at the top of the transition zone than at the bottom. This brecciation is particularly extensive within a large pillow sequence (Unit 63), between 910 and $930 \mathrm{~m} \mathrm{BSF}$, where a mineralized stockwork also occurs (see Alt, Honnorez, et al., this vol.): Toward the base of the transition zone pillow units become thinner and pillow margins are rare. The basalts are less clearly identifiable as pillows and are generally recognized only by their rubbly, brecciated, fine-grained character.

Thin flows in the transition zone (except Unit 66) lack any fining of grain size toward margins, in contrast to those in the upper zone. Frequency and thickness decrease with depth (compare Units 53 and 55, 10 and $9 \mathrm{~m}$ thick, respectively, in terms of lithology, or 3.35 and $1.31 \mathrm{~m}$ in terms of recovery, with Units 76,79 , and 86 from lower in the hole, $1.5,2.5$, and $1.5 \mathrm{~m}$ thick, respectively, in terms of lithology, or $0.28,1.34$, and $0.45 \mathrm{~m}$ in terms of recovery).

The remainder of the transition zone is composed of massive units (mostly of Type 1b) which increase in abundance toward the bottom of the zone. These massive units are medium to coarse grained and probably represent the centers of massive flow units, sills, or possibly dikes. In lithological terms they can vary from 1.5 to $8.0 \mathrm{~m}$ in thickness and usually have a uniform texture (see Figure 1.). Unit 80 is the one exception to this, fining toward its upper margin. Low recovery in Cores 86-88 inclusive (Fig. 1) has exaggerated the lithological thickness of massive units in this portion of the hole. Almost all the units from Units 65 to 92, inclusive, are highly fractured. This extensive fracturing (remembering that the depth of the lower boundary to the transition zone may be too great) corresponds with the extensive fracturing in the dike unit reported by Williams and Malpas (1972) and by Rosencrantz (1982) for the Bay of Islands Ophiolite Complex. Ophiolite studies by Kidd (1977) have shown that dike abundances increase from 20 to $70 \%$ in the crust over a distance of about $25 \mathrm{~m}$ in the Betts Cove ophiolite, and $50 \mathrm{~m}$ in the Bay of Islands and Cyprus ophiolites. Although it is difficult to draw any meaningful comparisons with Hole 504B because of the poor recovery, dike abundances increase dramatically at approximately $900 \mathrm{~m}$ BSF (i.e., the top of the transition zone) and again from $960 \mathrm{~m}$ BSF onward (presumably some of these massive units must be dikes). Study of downhole logs points to the upper of these two horizons as being comparable to the zone discussed by Kidd and, in the case of Hole 504B, it would appear to be in the order of at least $70-80 \mathrm{~m}$ thick.

\section{The Lower Zone (1055-1350 m BSF)}

The last pillow recovered was identified at $1055 \mathrm{~m}$ BSF (Unit 92). This marks the boundary of an underlying zone composed predominantly of massive units and dikes in which no pillows were recognized. This unit has been interpreted as a sheeted dike complex (Anderson et al., 1982a), as predicted from ophiolite models of the oceanic crust. The dikes were recovered with one or occasionally two chilled margins, most of which were steeply inclined $\left(50-60^{\circ}\right)$ to near vertical. Some of these are highly brecciated (Units 78, 102, 113, 118, and 124 in particular). Anderson et al. (1982a) suggest this may be the result of forceful dike intrusions, but on the whole this zone, except for Cores 98 to 100 inclusive, is far less brecciated than those overlying it. An interesting observation by Anderson et al. (1982a) show the dikes in Hole 504B to be chilled exclusively against a fine- 
grained to very fine grained host (preferential intrusion along margins of previous dikes?) and for the centers to be medium to coarse grained (Fig. 1) with subophitic textures.

Most of the basalts recovered from the lower zone are massive (Type 1b). Many of these show significant grain size variations, fining toward one or both of their implied margins. This is particularly well illustrated in Figure 1 . These are probably dikes but they are entered on Figure 1 as massive units so as to adhere to the classification scheme discussed earlier. Additional evidence supporting their origin as dikes comes from fracture data studies (Natland and Adamson, unpublished data). The remaining basalts are massive units with uniform texture.

Probably little significance can be placed on the thicknesses of dikes or massive units in this lower zone because the actual depths at which lithological boundaries occur are inferred. All the same, several interesting calculations can be made with the lithology in its present form. Intrusive contacts indicate a regional dip to the crust of about $30-40^{\circ}$ (i.e., dike contacts dip at $50-60^{\circ}$ from horizontal) exaggerating units cored from a vertical borehole by at least a factor of 2 . Thicknesses in Figure 1 can be corrected by this factor to give "true" dike widths. In the case of units with intrusive margins, widths are in the order of $1-2 \mathrm{~m}$ in about $50 \%$ of the dikes (Units 94, 98, 100, 102, 104, 107, 108, 113, 116, 120 , and 125), and 2.5-7.0 $\mathrm{m}$ in others. These corrected thicknesses would decrease the closer the dikes are to vertical. In the case of Unit 114, a 0.2 -m vertical intrusive contact can be seen. The mean dike thickness in ophiolites is $\sim 1 \mathrm{~m}(1.2 \mathrm{~m}$ in Cyprus, $1.4 \mathrm{~m}$ in the Bay of Islands; Kidd, 1977), but as Kidd observes, dike width distribution is a slightly skewed log normal distribution, so thicknesses from 0.1-6.4 m can occur. Such evidence would support the view that the dike thicknesses portrayed in Figure 1, assuming a regional dip of $30^{\circ}$ or less, are reasonable. A similar argument can be put forward for the massive units (remembering that these are probably dikes): maximum thicknesses here, assuming a $50^{\circ}$ dip at inferred margins, are in the order of a few centimeters up to $7.5 \mathrm{~m}$ (Unit 121). This would seem to suggest that even with the poor recovery rates in this portion of the hole, approximately $16.6 \%$ (Cores 96141 ), the division of the lower zone basalts into 57 lithological units was a reasonable figure. This would give an average unit thickness of about $2.4 \mathrm{~m}$, assuming the units are dipping at $60^{\circ}$ from vertical. However, if the crust at Hole 504B has a normal mean distribution to dike thickness of around $1 \mathrm{~m}$ (Kidd, 1977), then this average thickness is too high, and the number of units forming the lower zone of the hole must have been underestimated. A normal mean distribution to dike thickness of about $1 \mathrm{~m}$ would require about 100 units in this lower zone. This is almost double the number of units recognized by the petrologists from rock recovery, so possibly units were missed in describing the cores, or alternatively, whole units were lost during drilling.

\section{DISCUSSION}

The lithological evidence from Hole 504B appears to support the presence of three distinct zones in the ocean crust at this site, each with very different lithological compositions. Clearly, there is a dramatic change in the lithology at $1055 \mathrm{~m} \mathrm{BSF}$, where basement composed predominantly of pillows, hyaloclastites, thin flows, and massive flows and dikes suddenly changes into a basement composed entirely of massive units and dikes. The evidence supporting a transition zone between the two may be more tentative, but clearly, the frequency of dike occurrence in the crust rapidly increases at about $846 \mathrm{~m}$ BSF when compared to the crust above it. Logging evidence would support the presence of such a transition zone at approximately the depth indicated by lithological studies. The change in character of the crust is clearly recognizable on all the downhole logs and from borehole televiewer pictures (Newmark et al., this vol.). However, the logging evidence suggests that the transition zone is less thick than the $209 \mathrm{~m}$ currently assumed from Figure 1 (see Adamson and Cann, unpublished data). Identification of pillow basalts at the bottom of the transition zone must be viewed with reservations (low recovery and fractured appearance made the identification of lithological type particularly difficult in this portion of the hole), and I favor placing the boundary between the transition zone and the lower zone higher in the hole, possibly around $1000 \mathrm{~m}$ BSF (this is very much a personal opinion formulated while constructing Fig. 1). This placement would then give a transition zone about $150 \mathrm{~m}$ thick.

The natural division of the lithostratigraphy of Hole 504B into three zones by the petrologists from Leg 83 gives a structure to in situ oceanic crust essentially concordant with that of ophiolite complexes and supports an ophiolite model for ocean crust structure of the kind proposed by Gass (1968), Moores and Vine (1971), and Cann $(1970,1974)$. Clearly, the crust in the area of the Costa Rica Rift is dramatically different from the crustal model proposed by Hall (1979) for the North Atlantic. The similarity of Hole 504B to an ophiolite stratigraphy strongly supports the theory that ophiolites are obducted pieces of oceanic crust. This of course assumes that the ocean crust in the area of the Costa Rica Rift is not excessively abnormal in structure. From the ophiolite model we can now be almost certain that further drilling at this site would ensure penetration of a dikegabbro transition zone, followed by gabbros, and finally layered cumulates.

\section{ACKNOWLEDGMENTS}

This paper would not have been possible without the combined efforts of all the petrologists associated with Hole 504B, and I gratefully acknowledge their work in the describing of cores and construction of early lithologies. Particularly, I would like to thank Rolf Emmermann, Pam Kempton, Jeff Alt, and Christine Laverne from Leg 83; as a team we identified, argued over, and described one hundred lithological units from the bottom of Hole 504B. Their application to detail alone made this paper possible. Also I would like to thank Nick Pertsev 
from Leg 69 for his work on the top $115 \mathrm{~m}$ of the hole. Thanks go to Joe Cann for his valuable advice in the writing of this paper, to Kay Whittle for helping with the early draft of Figure 1, to Christine Jeans for her help in designing the final copy, and to Keir Becker for reviewing the manuscript. This work was supported by a grant from the Natural Environment Research Council.

\section{REFERENCES}

Anderson, R. N., Honnorez, J., Becker, K., Adamson, A. C., Alt, J. C., Emmermann, R., Kempton, P. D., Kinoshita, H., Laverne, C., Mottl, M., and Newmark, R. L., 1982a. DSDP Hole 504B, the first reference section over $1 \mathrm{~km}$ through Layer 2 of the oceanic crust. Nature, 300:589-594.

,1982b. On Costa Rica Rift-Challenger drills deep into basement. Geotimes, 27:26-28.

Bodvarsson, G., and Walker, G. P. L., 1964. Crustal drift in Iceland. Geophys. J. R. Astr. Soc., 8:285-300.

Cann, J. R., 1970. New model for the structure of the oceanic crust. Nature, 226:928-930.

1974. A model for ocean crustal structure developed. Geophys. J. R. Astr. Soc., 39:169-187.

Cann, J. R., and Von Herzen, R. P., 1983. Downhole logging at Deep Sea Drilling Project Sites 501, 504, and 505, near the Costa Rica Rift. In Cann, J. R., Langseth, M. G., Honnorez, J., Von Herzen, R. P., White, S. M., et al., Init. Repts. DSDP, 69: Washington (U.S. Govt. Printing Office), 281-300.

CRRUST, 1982. Geothermal regimes of the Costa Rica Rift, East Pacific, investigated by drilling, DSDP-IPOD Legs 68, 69 and 70 . Bull. Geol. Soc. Am., 93:862-875.
Gass, I. G., 1968. Is the Troodos Massif of Cyprus a fragment of Mesozoic Ocean Floor? Nature, 220:39-42.

Hall, J. M., 1979. A model for the structural state of the upper half kilometer of North Atlantic oceanic Layer 1. In Talwani, M., Harrison, C. G., \& Hayes, D. E. (Eds.), Deep Drilling Results in the Atlantic Ocean: Oceanic Crust. Am. Geophys. Un. Maurice Ewing Series 2:166-168.

Hall, J. M., and Robinson, P. T., 1979. Deep crustal drilling in the North Atlantic Ocean. Science, 204:573-586.

Kidd, R. G. W., 1977. A model for the process of formation of the upper oceanic crust. Geophys. J. R. Astr. Soc., 50:149-183.

Lonsdale, P. F., and Spiess, F. N., 1980. Deep-tow observations at the East Pacific Rise, $8^{\circ} 45^{\prime} \mathrm{N}$, and some interpretations. In Rosendahl, B. R., Hekinian, R., et al., Init. Repts. DSDP, 54: Washington (U.S. Govt. Printing Office): 43-62.

Moores, E. M., and Vine, F. J., 1971. The Troodos Massif, Cyprus, and other ophiolites as oceanic crust: evaluation and implications. Phil. Trans. R. Soc. Lond. A., 268:443-466.

Natland, J. H., and Rosendahl, B.. R., 1980. Drilling difficulties in basement during Deep Sea Drilling Project Leg 54. In Rosendahl, B. R., Hekinian, R., et al., Init. Repts. DSDP, 54: Washington (U.S. Govt. Printing Office): 593-603.

Rosencrantz, E., 1982. Formation of uppermost oceanic crust. Tectonics, 1:471-494.

Williams, H., and Malpas, J., 1972. Sheeted dykes and brecciated dyke rocks within transported igneous complexes, Bay of Islands, western Newfoundland. Can. J. Earth Sci., 9:1216-1229.

Date of Acceptance: 16 January 1984 